\title{
The Existence of Local Wisdom in the World Bank Post- Earthquake Assistance Implementation in West Sumatra
}

\author{
${ }^{1}$ ANITA AFRIANI SINULINGGA, ${ }^{2}$ SILSILA ASRI, ${ }^{3}$ SOFIA TRISNI \\ 1, 3 Universitas Andalas, Kampus Limau Manis Padang, Indonesia \\ 2STISIP Imam Bonjol Padang, Jl.Koto Tinggi, Jati Baru Padang, Indonesia \\ email: ${ }^{1}$ anitaafriani@soc.unand.ac.id; 2la tansa2003@yahoo.com; 3sofiatrisni@soc.unand.acid
}

\begin{abstract}
This research concludes that the development success which used the Community Driven Development (CDD) approach such as PNPM Mandiri (National Program for Community Empowerment) is influenced by local wisdom in each region. The CDD approach focuses on the active participation of society's various elements which aims to empower and increase the independence of the community in achieving welfare. The West Sumatran local wisdom is the traditional Minangkabau philosophy of 'adat basandi syarak, syarak basandi kitabullah ', highlighting the valued relation between traditions, religion, and the holy book of the Quran. The strong integration of the Minangkabau community's social order with this philosophy creates its own participation characteristics which become the basis for the CDD approach development implementation. By using qualitative research methods, with in-depth interview techniques and purposive sampling, this study discovered dualism that contradicted the synergy of customary principles and the CDD approach: the World Bank's development approach normatively aligned with the Minangkabau traditional philosophy values, however, this conformity is counterproductive to the achievement of post-disaster community empowerment goals.
\end{abstract}

Keywords: wisdom, community, empowerment

\section{Introduction}

The earthquake which occurred on September 30, 2009 in West Sumatra proved to have negative influence on the province's economic performance and has increased the number of impoverished people. The World Bank is one of the international donor agencies which has been consistent in providing development assistance to developing countries including Indonesia (Wong, 2012). This institution conducts approximately 400 projects of Community Driven Development/CDD in 94 countries with a value of nearly US $\$ 30$ billion which were distributed to various areas affected by disasters. One of these CDD development projects is PNPM Mandiri in Indonesia.

This study concludes that the success of the PNPM Mandiri program depends on the harmonization process or synergy between cultural values and local wisdom with the values and universal principles of CDD approach in international development, especially in the implementation of PNPM Mandiri projects. PNPM Mandiri's mission is poverty alleviation. (Setyobudi, 2012) explains that in essence, poverty is multidimensional, therefore poverty alleviation programs should not only prioritize economic aspects but also focus on other dimensions. In other words, provision of basic needs is a priority, however it should not eclipse resolving non-economic poverty. This research describes the probability of clash of values and principles between indigenous peoples and the implementation of the PNPM Mandiri development program which displays universal principles.

To achieve the goal of poverty alleviation, governance supported by the synergy between various components is needed. (Susilo, 2015) explains that PNPM which is funded by the World Bank and is based on

Received: 2018-09-05, Revised: 2019-04-01, Accepted: 2019-05-29

Print ISSN: 0215-8175; Online ISSN: 2303-2499. DOI: http://dx.doi.org/10.29313/mimbar.v35i1.4053

Accredited $\mathbf{S 2}$ based on the decree No.10/E/KPT/2019 until 2024. Indexed by DOAJ, Sinta, Garuda, Crossreff, Dimensions 
the CDD principle is a complex governance system that requires supporting components including democracy, decentralization, rule of law, and public participation. This paper attempts to analyze the interaction between these components within the governance of PNPM World Bank. The findings of this article indicate that there are conflicts between components within the system which hinders reaching the initial goal of poverty reduction. Conversely, the obscurity in governance leads to two new problems: the rise of potential conflicts and elite domination.

Besides the issues of governance, power dynamics among actors involved in the program are also present in the PNPM implementation. Power is a necessity to empower the community. (Susilo, 2018) discovered that the PNPM implementation, especially based on the experience of PNPM in Malang Regency, East Java, was able to change the power level of actors from ordinary individuals to elites. If previously, the sources of power of elite groups were in material domination and position in formal institutions, this study reveals there are alternative sources of power that are more non-material in nature, namely loyalty, dedication, and trust.

Meanwhile, in analyzing the impact of the CDD approach in PNPM Mandiri projects in Indonesia, (Mccarthy et al., 2017) observed that it constructed a new mechanism parallel to the state development program to resolve the issue of powerless local institutions and authorities, especially in the New Order semiauthoritarian regime. Although facing various challenges from the established structural hierarchy, the PNPM Mandiri implementation was able to provide space for institutions outside the formal structure to participate in development programs. Furthermore, this became a reference for this study to discover the pattern of relations between actors involved in terms of social cohesion development.

Implication of PNPM Mandiri provides flexibility for the community by providing an open menu system. Based on the case study of Bantul district, Yogyakarta after the 2006 earthquake, (Kusumasari \& Alam, 2012) identified that this area succeeded in reimaging itself from a poor urban area with limited funds and capacity in disaster management to be an area with a planned development strategy which resulted in satisfying post-disaster recovery programs for the community. Local wisdom plays a role in the transition of the image. Specifically for this case, the community acted as the temporary policy maker, whereas the government became the provider of facilities and infrastructure for the community.

There has been previous research on PNPM Mandiri as an example of a CDDbased development project supported by international development assistance agencies, covering cases from several regions in Indonesia. However, these studies mostly examined the effectiveness of PNPM Mandiri program implementation. This article focuses on the existence of local wisdom values (Minangkabau indigenous culture) in West Sumatra and its encounter with the patterns and principles of the Community Driven Development (CDD) international development which is concretely enforced in the PNPM Mandiri program in post-disaster areas.

\section{Research Methodology}

The methodology of this research is qualitative and is designed in the form of a case study. The unit of analysis of this study is indigenous peoples and Nagari local communities in three areas of Agam Regency, Padang Pariaman Regency, and Padang City. These were the areas which suffered the worst impact in the 2009 earthquake. These three regions are also representatives of the Minangkabau indigenous people social structure, covering a wide range of characteristics. Pariaman Regency is a "rantau" location that has its own characteristics as a coastal area of West Sumatra. The city of Padang is the capital of West Sumatra with a more heterogeneous society structure which applied the same governance structure as other cities in Indonesia, which is not implementing the Nagari government system but rather the political district system. Agam and Padang Pariaman District implemented the PNPM Mandiri Rural program and Padang City applied the Urban PNPM Mandiri scheme.

The types of data used in this study are primary data and secondary data. Primary data was obtained from in-depth interviews directly from the subjects or informants. The selection of informants in this study used a purposive sampling technique, which were people related and directly involved in the research problems such as the village/ Nagari apparatus, bundo kanduang (women who lead 
a family in Minangkabau/female leaders), and Minangkabau indigenous community leaders. In the nagari government model, bundo kanduang and community leaders are one of the elements in the nagari deliberative assembly, that is a legislature at the nagari level. Meanwhile secondary data was gathered through documents related to the research topic, which are journal articles related to the principles of CDD and local wisdom, World Bank working paper documents, and reports on post-disaster community development activities in the West Sumatra region, mainly through PNPM Mandiri.

\section{Result And Discussion}

\section{Relations between Stakeholders in PNPM Mandiri West Sumatra}

According to the Indonesian Law Number 2 year 2004 concerning the national development planning system, rehabilitation and reconstruction activities are policies that are integrated in the national and regional development planning systems. The West Sumatra rehabilitation and reconstruction program after the earthquake in 2009 is an integral part of the RPJMN (National Medium-Term Development Plan) and RPJMD (Regional Medium-Term Development Plan) for 2010-2014 and covers a period of 18 (eighteen) months, starting from the 2009 to 2011 budget year following the applicable fiscal year.

The disaster management source of fund is a shared responsibility between the central and the regional government. The West Sumatra disaster relief fund derives from several sources including state and regional expenditure budget (ABPN/APBD), foreign grants, grants from companies/ private/national communities, and community self-help funds. The funding source is accommodated through the Sumatran Natural Disaster Assistance Account at Bank Indonesia. In addition, international assistance can be channeled through the West Sumatra Multi-Donor Fund scheme which is managed based on the provisions of the law and government decree. The amount of humanitarian aid funds for West Sumatra is described in table 1.

Table 1 report the largest humanitarian foreign assistance for disaster relief in West Sumatra-Indonesia originates from the World Bank. PNPM Mandiri is one of the three poverty alleviation programs launched by the government in the 2010-2014 RPJMN (Triyono, 2013). The aim of this program is to provide assistance and debriefing to enable the impoverished people to determine their direction, steps, and efforts to utilize available resources in order to alleviate themselves from poverty (Baker et al., 2013). The core of PNPM Mandiri is a community empowerment program aimed at improving community welfare.

\section{Table 1}

Largest Estimated Assistance Funds from Multilateral and Bilateral Sources

\begin{tabular}{|c|c|c|c|}
\hline No. & Activity & $\begin{array}{l}\text { Amount } \\
\text { (Million) }\end{array}$ & $\begin{array}{c}\text { Fund } \\
\text { Source }\end{array}$ \\
\hline 1 & Urban PNPM & USD 20-30 & World Bank \\
\hline 2 & Rural PNPM & USD 17 & World Bank \\
\hline 3 & WINRIP & USD 6 & World Bank \\
\hline 4 & PAMSIMAS & USD 5 & World Bank \\
\hline 5 & ILGR & USD 3 & World Bank \\
\hline 6 & $\begin{array}{l}\text { Early } \\
\text { Childhood } \\
\text { Education } \\
\text { and } \\
\text { Development }\end{array}$ & USD 1,5 & World Bank \\
\hline 7 & WASAP & USD $0,5-1$ & World Bank \\
\hline 8 & Project & USD $18-25$ & $\begin{array}{l}\text { Asian } \\
\text { Development } \\
\text { Bank }\end{array}$ \\
\hline 9 & $\begin{array}{l}\text { Asia Pacific } \\
\text { Disater } \\
\text { Response } \\
\text { Fund }\end{array}$ & USD 3 & $\begin{array}{l}\text { Asian } \\
\text { Development } \\
\text { Bank }\end{array}$ \\
\hline 10 & IDB & USD 30,5 & $\begin{array}{l}\text { Islamic } \\
\text { Development } \\
\text { Bank }\end{array}$ \\
\hline 11 & UN-Family & USD 38,5 & $\begin{array}{l}\text { United } \\
\text { Nation }\end{array}$ \\
\hline
\end{tabular}

Source: (Bappenas, 2010)

The process of rehabilitation and reconstruction is based on the disaster management law in Indonesia -Law No. 24 year 2007- which requires a Community Based Disaster Risk Management (CDRM) process in planning, implementing and monitoring disaster management programs. In this case, the role of local government as a driving force for post-disaster reconstruction is very important. In this approach, the local government is not limited to the provincial and district/city governments, but also encourages an active participation of sub-district, village, and community governments in accordance with local cultural characteristics.

One of the local culture characteristics which must be clearly recognized by every 
stakeholder involved in the West Sumatra village governance which is different from other villages in Indonesia. Village government in West Sumatra is called the Nagari Government. Nagari is an autonomous government based on the community or 'selfgoverning community' as a manifestation of the characteristics of the communal Minangkabau indigenous people. Nagari is the lowest village level government in West Sumatra. Each Nagari has a government organizing element consisting of the Nagari Government as the executor of government affairs and the Nagari Deliberation Assembly (Bamus Nagari) as an institution that embodies democracy in the administration of Nagari government. The Nagari Government consists of Wali Nagari (village head) and Perangkat Nagari while Bamus Nagari is a representative of the community such as Ninik Mamak/traditional or tribal leaders, Alim Ulama/religious leaders, Cadiak Pandai/ intellectuals, Bundo Kanduang/female leaders and other community actors which grows and develops in the Nagari by considering the representation of Jorong (the term for villages far from urban areas in West Sumatra) which is determined by means of deliberation and consensus.

On the field, this development program is guided by Operational Technical Guidelines which contains principles that must be applied in the implementation of assistance. These guidelines refer to agreements and standard conditions required by the World Bank. Structurally and institutionally, PNPM Mandiri is conducted in stages starting from the Central Government to the Regional Government. The line of authority is decentralized, referring to the Indonesian government system and the CDD approach principle which emphasizes the improvement of local/regional government capacity and governance. The World Bank acts as a source of funding and also as the stakeholder who will demand accountability and reports on the implementation of PNPM Mandiri, specifically for disaster rehabilitation. At the central government level, a command team and the PNPM Mandiri team were formed, led by the Coordinating Minister of the People Welfare as Chair of the Poverty Reduction Coordination Team (PNPM, 2007).

Furthermore, highlighted in the Operational Technical Guidelines is that local government, in this case nagari/kelurahan, does not have a clear structural authority in PNPM implementation governance. The elite of the nagari and village administrations are in the same position as the people who are targeted by the program. The Management Team (TPK) and facilitator were assigned from the District Government and the issuance of funds disbursement documents was also issued by the subdistrict head. As a result, in some regions, the nagari/kelurahan elite did not participate in PNPM Mandiri activities, considering it was not a part of their responsibility.

\section{The synergy of West Sumatra Local Wisdom with World Bank Develop- ment Principles through the PNPM Mandiri Program}

Based on literature studies and interviews with several community leaders in the research area, the study discovered that in general, the CDD principles is in harmony with Minangkabau culture. However, on the other hand, this harmony does not always positively contribute to the successful implementation of PNPM Mandiri, specifically for disaster rehabilitation. Important findings from the patterns evaluation of PNPM Mandiri implementation, particularly for rehabilitation and reconstruction in West Sumatra, can be explained as follows.

\section{Relying on Human Development}

The CDD concept is an alternative solution from the World Bank to critics stating that the agency gives little attention to the impacts of its funded project towards humans and the environment. In simpler terms, the CDD provides control of decisions and resources to community groups. The impoverished are not seen as recipients of assistance; CDD considers the community more as a partner in the hope that the community has a sense of ownership and empowerment towards the development of projects conducted (Wienecke, 2005). But the goal of CDD implementation has not been achieved, one of the obstacles was due to social capital that was not involved in the development program (Casey, 2017). Local wisdom values are social capital in development. (Kusumasari \& Alam, 2012) explained that the local wisdom-based recovery model can be applied in regional government models that have strong local cultural characteristics.

PNPM Mandiri disaster rehabilitation aims to restore human dignity by restoring 
social and public facilities that support the economic, educational, and social activities of the community. In the reconstruction of infrastructure damaged by the earthquake, the program was considered successful. However, it as less productive as a stimulant assistance funds channeled through a special savings and loan fund for women groups. There are several factors which explain why this savings and loan scheme are less productive. Firstly, because they are used more for consumptive activities; and secondly, people were reluctant to use these funds. By understanding this from the Minangkabau local wisdom approach, it is realized that applying for loans from outside of the community is not in accordance with the principle of maintaining one's dignity. Customs and Minangkabau religions preach the importance of valuing dignity and maintaining wisdom. Applying for a loan is looked down upon within the community, based on the belief that it will cause shame, not only for the person, but also for relatives the people of the community concerned.

\section{Autonomy}

In the CDD scheme, the community is given independent authority to participate in determining and managing development activities in a self-managed manner. (Kusumasari \& Alam, 2012) explained that the success of post-disaster recovery efforts depends on respecting and utilizing local culture and local wisdom. In principle, the community itself must decide how to rebuild its life after the disaster while the regional government acts as a support of the development program.

The Minangkabau people local wisdom to mobilize self-management participation actually exists, manifested through material and non-material contributions. Nonparticipation in donating resources will damage the dignity of a people. But in the implementation of PNPM Mandiri, autonomy in post-disaster conditions is very difficult to implement. Post-disaster communities need more policy and rapid action, with instructional tendencies. The expected self-management in the rehabilitation and reconstruction control can hardly be mobilized internally. PNPM Mandiri experienced several obstacles in its implementation process, especially related to individual involvement in the development. Many individuals involved in rebuilding damaged facilities were more motivated by the daily wages offered in accordance with PNPM Mandiri's technical guidelines specifically for disaster rehabilitation. This is different from PNPM Mandiri, which requires self-help and self-management.

\section{Decentralization}

The CDD approach enriches the ideas of decentralization regarding participation in community empowerment, especially for the impoverished. This approach minimizes the control of aid agencies in the process of selecting, implementing, and managing the financial sector of the community. The authority to manage sectoral and regional development activities is delegated to local governments or communities, according to their capacity. In the CDD approach, decentralization and autonomy are intended to strengthen institutional capacity and local governance. In the Minangkabau traditional philosophy, the social order is hierarchical which is expressed by the expression of "bajanjang naik, batanggo turun". It implies that everything in society has its own structure and functions which are hierarchical in nature and everything must be placed in its position and according to its function.

In the process of post-disaster rehabilitation and reconstruction, decentralization and autonomy are manifested in inter-village meetings. The active involvement of regional government, in this case nagari, is not present in PNPM Mandiri projects. This is because structurally and institutionally, PNPM Mandiri does not have clear regulations regarding the role of nagari government and traditional institutions. PNPM Mandiri was implemented by an independent District Management Unit formed and responsible for the Regional Poverty Reduction Coordination Team, which is not under the coordination of nagari or sub-districts. The Regional Poverty Reduction Coordination Team reports to the Regent/ Mayor. The sub-district head as the highest leader in the sub-district has the role of issuing the Sub-District Determination Letter based on the inter-village meetings in the process of disbursing community direct assistance funds/BLM PNPM Mandiri.

Such a structure is normatively intended to provide autonomy to the community in managing development programs, to simplify the bureaucratic process, and to avoid the program being controlled by the nagari elite group. (Mccarthy et al., 2017) explains that CDD interventions can have positive impact in increasing state legitimacy, expanding the strength of state infrastructure and 
government capacity, and contributing to the cumulative experience with local development programming.

However, this was not considered as appropriate in the governance structure of the people in Minangkabau who implements the Nagari system. The lack of authority in local institutions, particularly nagari government and customary institutions, led to a lack of institutional participation which can be used to mobilize community participation. A development community program which does not include nagari leaders (adat/custom and government) will often result in lack of ownership and togetherness towards the program.

Consequentlly, most of the people and even the nagari leaders perceive the program as the responsibility of the District Management Unit, whereas the community act as beneficiaries. Generally, PNPM Mandiri in West Sumatra is less successful in strengthening the capacity of local institutions and local governance, in this case nagari, as one of the principles of CDD. This also contributes to the lack of participation and sense of community ownership of the program. Similar findings were discovered by (Casey, 2017) where the application of CDD was proven to be effective in providing goods for community needs and simple economic stimulus in the form of investment. Nevertheless, the CDD has not been able to influence the level of community participation in policy making at the local level or in the empowerment of the impoverished.

\section{Community Involvement}

Community participation through the CDD scheme is conducted by involving the opinions of individual stakeholders, community groups, and NGOs in planning, implementing, and building a sense of ownership in development programs (Wienecke, 2005). The principle of participation in the CDD approach is parallel with the concept of participation in the Minangkabau indigenous philosophy, where each member of the community can actively participate in the program according to their capabilities and potential. The most common indicator of achievement to measure community participation in PNPM Mandiri is through community involvement in deliberations to choose the future development program to be implemented.
(Bealt \& Mansouri, 2018) described community participation as a form of ad hoc networks having the ability to meet various disaster management needs. This structure, characterized as Collaborative Aid Networks (CANs), has demonstrated efficient logistics management capabilities outside humanitarian agencies. Meanwhile, the CDD case in the Philippines, (Labonne \& Chase, 2011) discovered that CDD development projects were able to increase participation in village assemblies and also the frequency of meetings between local officials and residents but had negative impact on collectivity and bridging the trust between members in groups. The non-involvement of the impoverished and vulnerable groups in the reconstruction process in Nepal undermines the hope of building resilient communities against disasters. Learning from Nepal case, (Lam \& Kuipers, 2019) emphasizes the importance of empowerment in building resilience. Without empowering the local community, resilience will only function as a mere slogan and lose its effectiveness.

Several research results on PNPM Mandiri indicate that the level of community participation is still low in each deliberation aimed at program implementation. In general, low participation in the community is caused by the lack of understanding towards the objectives and nature of PNPM Mandiri. The reluctance of community participation is caused by several factors such as perception of deliberation as a cause of loss and lack of encouragement from niniak mamak. It is crucial to highlight that the involvement of traditional, religious, and government leaders is of utmost importance to mobilize community participation because the Minangkabau community members obey their leaders, especially traditional and religious ones.

\section{Gender Equality and Justice}

In Minangkabau tradition and culture, women have a respectable and special position. Women are considered as chosen ones and are called bundo kanduang. In accordance with era changes, Bundo Kanduang's role is no longer only domestic but also public. (Beath, Christia, \& Enikolopov, 2017) discovered the positive impact on the existence of women in post-disaster development programs. The National Solidarity Program (NSP), a community-based development program in Afghanistan, presented positive influence on perceptions of gender and women's roles. These findings provide strong justification for 
NSP policies to mandate women's participation in the selection of programs, composition, and management of the CDD subproject, which has resulted in changes in women's lives that far exceed the scope and cycle of program implementation.

The meaning of equality in the position of women and men in Minangkabau cannot be defined as the equality referred to in the CDD, but women have an important position in the social order of the Minangkabau people who adhere to the matrilineal system (maternal lineage). This position is crucial in the success of the development program. However, when a development program does not involve the authority of customary institutions in which there are elements of bundo kanduang, women's participation in the program is also very low. The majority of the meetings were attended by men because Minangkabau women worked mostly 'behind the scenes'.

The limited role of women in the postdisaster recovery process was also found in several cases. (Sadiqi, Trigunarsyah, \& Coffey, 2017) discovered that gender issues became an obstacle in the post-disaster housing reconstruction project in Afghanistan, which is the lack of women's participation in the development process. In line with Sadiqi, (Steffen \& Steffen, 2014) also found limited women participation in the CDD program known as the Rural Development Program (RDP) in the Solomon Islands. The RDP process mandates the involvement of women, especially in selecting community infrastructure projects and participating in the RDP subcommittee known as the Sub Implementation Committee (SIC). While the program has helped increase women's participation in the RDP project and process, it is suggested that the involvement of women outside the program is still limited.

In PNPM Mandiri, funds channeled in the form of women's special savings and loans are aimed at empowering households. In some areas this program has been implemented, however many loans are used for consumptive activities. In other areas, the funds were not utilized because of the self-esteem problems and shame of the Minangkabau community. Minangkabau local wisdom has its own regulations for loans or inheritance. For example, lending is permissible if the house is blocked, which means being in conditions of crisis or disaster. Borrowing can only be done with the agreement of mamak and bundo kanduang and is not encouraged to be done outside of familial ties.

\section{Democratic}

By embracing a bottom-up approach to development, the CDD puts pressure on empowering local communities to select and manage projects that best suit the needs of local communities. The NSP in Afghanistan had a positive effect on the democratic process, especially in policy-making through both CDD schemes and other programs in Afghanistan. The NSP approach has succeeded in facilitating the acceptance of democratic norms and the participation of women and other marginalized groups in public affairs (Beath et al., 2017).

Democratic social order is a major leadership character of in the Minangkabau indigenous people. Within the Minangkabau democratic system, reaching an agreement is highly prioritized, without any choice for voting. The symbol of tuah sakato implies that all affairs in the family, people, and nagari are discussed according to their respective levels. Mamak is a leader in a family; the leader is a tribal leader and as the highest decision maker, they deliberate to reach consensus.

The system of democracy of the Minangkabau people does not provide room for everyone to be involved in the nagari deliberation activities because the activities are for traditional leaders and clan leaders only. The opportunity for an individual to involve is in the deliberations of people and tribal meetings. The tribal agreement will then be defended by tribal representatives in the nagari deliberation. Since the CDD approach principle of democracy is not able to synergize with Minangkabau indigenous democracy principle, many of the nagari deliberations could not involve the target community groups which are the impoverished people.

The issue of community participation in policy making at the local level as well as in the empowerment of the impoverished becomes counter-productive because of the emergence of exclusive local. The elite group has a more dominant role in policy making (Casey, 2017). (Ahmad \& Abu Talib, 2015) also discovered similar findings in the decentralization in Pakistan through the establishment of a community-based organization initiative, called the Citizen Community Board (CCB's). The existence of these groups had a positive impact on community empowerment and the sustainability of specific project at the local 
level but lacked a sense of togetherness and mutual benefits for rural communities. The fundamental purpose of decentralization seems to be difficult to understand because power is only transferred at the local level with little support for community capacity building and limited public access to resources and existence of elite groups that control policies in the electoral process.

\section{Transparency and Accountability}

The community must have adequate access to information and decision-making processes in order to have an open and accountable activities management which are acceptable morally, technically, legally, and administratively. (Bealt \& Mansouri, 2018) explains that community participation in humanitarian logistics provision activities are conducted through an ad hoc network that has the ability to meet various disaster management needs. Collaborative Aid Networks (CANs) have demonstrated efficient logistics management capabilities outside the existing humanitarian organizations. One of the benefits of community-based post-disaster operations is the collaborative nature of networks at the local level enabling increased distribution of resources and information regarding community needs in the recovery period.

In line with the democratic system and the prevailing social order in the nagari community, transparency and accountability intended in PNPM Mandiri is often faced with challenges. Public understanding of the objectives and nature of the program is still low because people of the community believe more on the information from "mouth to mouth" rather than through the dissemination of official information or meetings related to socialization or explanations of the program. Transparency and accountability also failed to be maintained by the Minangkabau people, having the habit to prioritize their relatives. A common case is community assistance for the impoverished will be received by community members who have familial relations with the most dominant nagari leaders. The importance of prioritizing relatives is also a dilemma for facilitators and appointed staff from village and sub-district community members because they also represent a group of people or ethnic groups; thus, by not prioritizing relatives, they will be considered to have mistreatedt their own families.

\section{Sustainability}

Through a community network of the Citizen Community Board (CCB's) at the local level in Pakistan, (Ahmad \& Abu Talib, 2015) explains that there is a positive influence of community empowerment on the community-based development projects sustainability. However, community still experience limitations, therefore ongoing support from local governments is needed to encourage the local rural economy. Likewise, participatory community-regional development strategies can achieve a sense of ownership and empowerment among rural communities. The collaborative nature of the humanitarian organization network can also be seen in Collaborative Aid Networks (CANs). CAN's involvement in humanitarian operations resulted in the increase of disaster-affected communities' resilience and the reduction of potential future disasters vulnerability (Bealt \& Mansouri, 2018).

Every decision-making process must consider the importance of improving the community in the short and long term. Analysis of the harmony between Minangkabau indigenous philosophy and CDD principles illustrates two conditions of synergy. In certain aspects, the norms, customs, and principles of Minangkabau wisdom and the CDD principles mutually support and strengthen each other, especially in the aim of achieving a human-centered development, respecting the role and position of women in development, democracy participation, autonomy, and decentralization. But in its implementation, the same norms, customs, values, and principles of Minangkabau wisdom are not in harmony with the CDD principles. As the result, they do not positively contribute to the achievement of PNPM Mandiri goals. In addition, the social capital formed during the implementation of the program is temporary and does not become the capital for further development. The provision of stimulant funds and economic development facilities is at times not utilized for empowerment and the achievement of economic independence for the impoverished people.

\section{Conclusions}

The CDD approach through PNPM Mandiri, specifically in disaster rehabilitation, was aimed to empower and fulfill people's basic needs. However, its implementation was challenged by Minangkabau people's values and habits. There was a contradictory dualism 
in Minangkabau customary principles and the CDD synergy; in certain aspects it can be mutually reinforcing, but in others, it becomes counterproductive towards achieving the goal of community empowerment. As the result, the reduced percentage of impoverished people in West Sumatra was not followed by maximum results in empowering, developing and sustaining their independence.

The analysis on PNPM Mandiri's approach concluded four achievements. First, strengthening local institutions and local governance capacity. In the institutional structure of PNPM Mandiri, the nagari and traditional government elite were not directly involved in order to avoid elite domination. Their role was to mobilize the community's participation in internagari and nagari deliberations. Second, is the tribe representative's participation which then leads to domination in program implementation such as in Agam and Pariaman Regencies (homogenous areas). In heterogeneous areas (eg. Padang), community participation is not represented by the leadership of the people, and yet program achievement remains low due to apathy towards the program and disinterest due to lack of incentives. The third is the presence of independence and community empowerment not because of the program but as the result of least three conditions: lack of community understanding on the program objective, the dominance of the nagari and traditional elite, and prioritization of community members highly connected with the elites. Fourth is women's participation such as provides wider space for women involvement although limited to technical aspects rather than policymaking.

\section{References}

Ahmad, M. S., \& Abu Talib, N. B. (2015). Empowering local communities: decentralization, empowerment and community driven development. Quality and Quantity, 49(2), 827-838. https:// doi.org/10.1007/s11135-014-0025-8

Baker, J. L., Burger, N., Glick, P., PerezArce, Francisco Rabinovich, L., Yoong, J., Sikoki, Bondan Suriastini, W., ... Weetjens, J. (2013). "Indonesia Evaluation of the urban community driven development program : Program Nasional Pemberdayaan Masyarakat Mandiri Perkotaan (PNPM-Urban). (January).

Bappenas. (2010). Rencana Aksi Rehabilitasi dan Rekonstruksi Erupsi Gunung Merapi
Provinsi DIY dan Jawa Tengah Tahun 20112013. Jurnal Perencanaan Wilayah Dan Kota, 21(1), 1-129.

Bealt, J., \& Mansouri, S. A. (2018). From disaster to development: a systematic review of community-driven humanitarian logistics. Disasters, 42(1), 124-148. https://doi.org/10.1111/disa.12232

Beath, A., Christia, F., \& Enikolopov, R. (2017). The national solidarity programme: Assessing the effects of community-driven development in Afghanistan. Development Assistance for Peacebuilding, 3312, 20-38. https://doi.org/10.4324/9781315113289

Casey, K. (2017). Radical Decentralization: Does Community-Driven Development Work? (No. 3598).

Kusumasari, B., \& Alam, Q. (2012). Local wisdom-based disaster recovery model in Indonesia. Disaster Prevention and Management: An International Journal, 21(3), 351-369. https://doi. org/10.1108/09653561211234525

Labonne, J., \& Chase, R. S. (2011). Do community-driven development projects enhance social capital? Evidence from the Philippines. Journal of Development Economics, 96(2), 348-358. https://doi. org/10.1016/j.jdeveco.2010.08.016

Lam, L. M., \& Kuipers, R. (2019). Resilience and disaster governance: Some insights from the 2015 Nepal earthquake. International Journal of Disaster Risk Reduction, 33(August 2018), 321-331. https://doi. org/10.1016/j.ijdrr.2018.10.017

Mccarthy, J. F., Steenbergen, D. J., Warren, C., Acciaioli, G., Baker, G., Lucas, A., \& Rambe, V. (2017). Community Driven Development and Structural Disadvantage: Interrogating the Social Turn in Development Programming in Indonesia. Journal of Development Studies, 53(12), 1988-2004. https://doi. org/10.1080/00220388.2016.1262024

PNPM. (2007). Petunjuk teknis operasional program nasional pemberdayaan masyarakat mandiri perdesaan pola khusus rehabilitasi pascabencana.

Sadiqi, Z., Trigunarsyah, B., \& Coffey, V. (2017). A framework for community participation in post-disaster housing reconstruction projects: A case of Afghanistan. International Journal of Project Management, 35(5), 900-912. https:// doi.org/10.1016/j.ijproman.2016.11.008

Setyobudi, Y. F. (2012). Pengentasan Kemiskinan Melalui Program Nasional Pemberdayaan Masyarakat (PNPM) Mandiri. Dimensi, 1(3), 176-189. 
Steffen, E. M., \& Steffen, E. M. (2014). Women's Empowerment and CommunityDriven Development: Evidence from the Solomon Islands Women 's Empowerment and Community-Driven Development: Evidence from the Solomon Islands. The University of San Francisco.

Susilo, A. T. H. (2015). Program Nasional Pemberdayaan Masyarakat (PNPM) in Indonesia: The Challenge of Governance. Transformasi Global, 2, 1-19.

Susilo, A. T. H. (2018). Institutional Settings in Poverty Reduction Program: A contribution to the raise of new elites in rural Java. Politika, 9 (Oktober 2018), 6-19.

Triyono, B. (2013). Evaluasi PNPM Mandiri. Jakarta.

Wienecke, D. (2005). Community-Driven Development in Central Asia: A World Bank Initiative A Change of Strategy: Community Participation in World Bank development projects. Critique, (Spring 2005).

Wong, S. (2012). Susan Wong-What have been the impacts of World Bank Community-Driven projects (No. 69541). 